\author{
Anna Dąbrowska \\ Uniwersytet w Białymstoku \\ anna.dabrowska1804@gmail.com
}

Katarzyna Jarnutowska

Uniwersytet w Białymstoku

k.jarnutowska@wp.pl

\title{
Wybrane problemy związane $z$ wprowadzeniem do ustawodawstwa polskiego regulacji prawnych dotyczących tzw. testamentów życia
}

\section{Will of life as a challenge for the Polish legislator - selected problems}

\begin{abstract}
Proposals to regulate life associated problems in Poland cause interest and are discussed both on the social and doctrinal plane. The issue is controversial because it concerns the very delicate sphere of human life. This particular work is an attempt to define the "will of life". We say that this is a pro futuro statement, where each person can express his or her willingness to use specific medical procedures in anticipation of a future terminal condition. We then discuss the form and scope of the will and try to determine how much the doctor is bound by the patient's independent will which is expressed in the testament of life. In our work, we conducted an analysis of Supreme Court case law in order to consider problematic issues. We also dealt with the difficult questions of the topicality of will of life to finding a patient in a particular medical situation, because the will of man can change significantly as a result of illness. A healthy person judges the value of life well but his will can change over time. In conclusion, we present arguments for and against the acceptance of wills of life. We discuss the need to regulate the above issues in Poland and point to how solutions adopted in other countries might fit in the field of domestic legislation.
\end{abstract}

Keywords: will of life, pro futuro statement, terminal state

Słowa kluczowe: testament życia, oświadczenie pro futuro, stan terminalny 


\section{Wstęp}

Dyskusja nad problematyką testamentów życia ma charakter fundamentalny, ponieważ dotyczy niezwykle delikatnej części ludzkiego istnienia, jaką jest moment śmierci oraz jej godność ${ }^{1}$. Zagadnienie to wywołuje ogromne zainteresowanie oraz stanowi przedmiot szerokiej dyskusji, zarówno społecznej, jak i doktrynalnej. Przeciwnicy uważają, że jest to próba wprowadzenia do porządku prawnego zakamuflowanej zgody na przeprowadzanie eutanazji. Natomiast zwolennicy są zdania, że regulacja ta stanowiłaby dowód respektowania wolnej woli człowieka, bowiem on sam może decydować o momencie i sposobie, w jaki chce zakończyć swoje życie².

$\mathrm{W}$ niektórych zagranicznych ustawodawstwach kwestie związane $\mathrm{z}$ testamentami życia zostały już uregulowane, natomiast Polska nie ratyfikowała Europejskiej Konwencji Bioetycznej ${ }^{3}$, co za tym idzie, w polskich przepisach brak jest określonych standardów postępowania. Normy deontologiczne także nie stanowią nic na temat deklaracji antycypowanych, które mógłby złożyć pacjent $\mathrm{w}$ wypadku niemożności złożenia oświadczenia woli. Tymczasem uregulowanie problemu wywoła pozytywne następstwa w dziedzinach nauk tak medycznych, jak i prawnych.

Niniejsza praca ma na celu wyjaśnienie definicji, formy, a także warunków złożenia tego typu oświadczenia pro futuro oraz stanowi próbę skonstruowania w tej mierze postulatów de lege ferenda.

\section{Próba zdefiniowania pojęcia „testament życia”}

W polskim porządku prawnym nie ma jednolitej definicji testamentu życia. Aby wyjaśnić to pojęcie, należy określić, czym są oświadczenia pro futuro, gdyż w nauce prawa medycznego wyróżnia się wiele ich postaci. Niewłaściwym jest stosowanie pojęcia testamentu życia do wszystkich oświadczeń pro futuro 4 .

Zdaniem M. Śliwki, testament życia to oświadczenie pacjenta o sprzeciwie wobec określonych interwencji medycznych względem jego osoby na wypadek utraty zdolności do świadomego wyrażania zgody5. Podobnie twierdzi J. Haberko, to wola pacjenta, wywodzona $z$ oświadczenia sporządzonego uprzednio przez samego pacjenta na wypadek utraty świadomości ${ }^{6}$ O testamencie życia możemy mówić wtedy,

$1 \quad$ E. Jachnik, Testament życia w świetle Europejskiej Konwencji Bioetycznej a możliwość składania oświadczeń pro futuro w prawie polskim, „Zeszyt studencki Kół Naukowych Wydziału Prawa i Administracji UAM” 2014, nr 4, s. 134.

2 B. Łabowicz, Testament życia, (w:) W cieniu czepka, „Biuletyn informacyjny dolnośląskiej okręgowej izby pielęgniarek i położnych" 2014, nr 2/268/luty, s. 9.

3 Konwencja o ochronie praw człowieka i godności istoty ludzkiej wobec zastosowań biologii i medycyny z 4 kwietnia 1997 r. z Oviedo. Polska podpisała konwencję w 1999 r., choć jeszcze jej nie ratyfikowała.

$4 \quad$ M. Śliwka, Testament życia i inne oświadczenia pro futuro - przyczynek do dyskusji, www.ptb.org.pl/pdf/sliwka testament_1.pdf (data dostępu: 30.03.2016 r.).

5 A. Górski, Testament życia, (w:) Tenże (red.), Leksykon pojęć prawa medycznego, Warszawa 2012, s. 232.

6 J. Haberko, Realizacja standardów bioetycznych w prawie polskim w zakresie oświadczeń pro futuro, (w:) L. Kondratiewa-Bryzik, K. Sękowska-Kozłowska (red.), Prawa człowieka wobec rozwoju biotechnologii, Warszawa 2013, s. 142 . 
Wybrane problemy związane z wprowadzeniem do ustawodawstwa polskiego...

gdy potencjalny pacjent składa oświadczenie na przyszłość w sytuacji, kiedy żadne zagrożenie jeszcze się nie zmaterializowało ${ }^{7}$. Należy także powtórzyć za przedstawicielami doktryny, że jest to szczególna manifestacja woli pacjenta, składana na wypadek utraty przytomności, dotycząca sposobu postępowania lekarzy z pacjentem ${ }^{8}$. Definicję tę rozszerza M. Safjan, który uważa, że oświadczenia te dotyczą szerszego katalogu przypadków niż tylko utrata przytomności. Nieświadomość należy rozumieć jako faktyczną niezdolność do samodzielnego rozeznania sytuacji i podejmowania decyzji ${ }^{9}$. Z kolei M. Syska precyzuje, że w przypadku testamentów życia byłaby to dyspozycja na wypadek utraty zdolności, odnosząca się jedynie do zaprzestania terapii w stanach terminalnych lub także eutanazji ${ }^{10}$.

Testament życia ma na celu zagwarantowanie osobie, która go sporządziła, kontroli nad działaniami i zaniechaniami, jakie będą wobec niej podejmowane w przyszłości. Pacjent znajdujący się w stanie pełnej świadomości określa swoje preferencje dotyczące akceptowanego trybu leczenia bądź jego braku, w sytuacji utraty kompetencji do wyrażenia takiej decyzji w przyszłości.

Bywa, że testament życia jest mylony z eutanazją, która przecież polega na pomocy drugiej osobie w pozbawieniu życia, na jej wyraźne żądanie i pod wpływem współczucia, wiąże się z tym także aktywne działanie. Natomiast testament życia to bierne uszanowanie przez lekarza woli chorego, w dużej mierze zbliżone do zaprzestania tzw. uporczywej terapii.

\section{Charakter prawny i forma oświadczenia}

Osoba sporządzająca testament życia podczas jego formułowania powinna przede wszystkim otrzymać niezbędne informacje dotyczące ewentualnych interwencji medycznych, które mogą być podjęte w stosunku do niej. W praktyce trudno jest dokładnie poinformować pacjenta, gdyż oświadczenie dotyczy wydarzeń przyszłych i niepewnych ${ }^{11}$. Z prowadzonych w latach 90 . badań wynika, że lekarze nie są należycie przygotowani do przeprowadzania rozmów z chorymi, pomimo nałożenia przez ustawodawcę takiego obowiązku' ${ }^{12}$.

Testament życia należy zaliczyć do grona jednostronnych czynności prawnych. Do jego skuteczności wystarczy samo złożenie oświadczenia woli przez potencjalnego pacjenta. Wola chorego w myśl zasady voluntas aegroti suprema lex est stanowi upoważnienie dla lekarza do podjęcia określonych interwencji medycznych bądź

$7 \quad$ M. Śliwka, Testament życia i inne oświadczenia pro futuro, op. cit., s. 11.

8 M. Syska, Medyczne oświadczenia pro futuro, Warszawa 2013, s. 33.

9 M. Safjan, Prawo i medycyna. Ochrona praw jednostki a dylematy współczesnej medycyny, Warszawa 1998, s. 44.

10 M. Syska, Medyczne..., op. cit., s. 41.

11 E. Jachnik, Testament życia..., op. cit., s. 141.

12 W. Chańska, Ewolucja dyrektyw na przyszłość w amerykańskiej praktyce medycznej. „Prawo i Medycyna” 2015, nr 1, s. 38. 
ich zaniechania w przyszłości. B. Janiszewska wskazuje, że jednostronne czynności, do których według orzecznictwa zaliczamy oświadczenia woli, podlegają zasadzie numerus clausus - zasada ta stanowi o dopuszczalności jedynie tych czynności, które zostały wymienione $\mathrm{w}$ przepisach. Brak unormowań dotyczących oświadczeń woli powinien skutkować ich niedopuszczalnością ${ }^{13}$. Brak regulacji prawnych prowadzi więc do sytuacji ograniczeń autonomii pacjenta. Jednostki posiadającej zdolność do podejmowania decyzji nie możemy pozbawiać tego prawa ze względu jedynie na utratę świadomości czy brak możliwości komunikowania swoich potrzeb. Tak samo zauważa M. Boratyńska: „... mielibyśmy zatem grupę pacjentów dorosłych, sprawnych umysłowo i jednocześnie całkowicie pozbawionych autonomii. Ten sam pacjent, dopóki przytomny, dysponowałby pełną autonomią. Czyli sama tylko fizyczna niemożność porozumienia, zakomunikowania i otrzymania odpowiedzi pociągałaby za sobą uchylenie autonomii, a jednocześnie pacjent nie miałby żadnej możliwości przeciwdziałania temu $\mathrm{z}$ wyprzedzeniem"14. Na ustawodawcę należy nałożyć obowiązek skonstruowania przepisów, które nie będą ograniczały autonomii i swobody decydowania jednostki również w przypadku utraty przez nią świadomości.

Według M. Śliwki, regulacja dotycząca oświadczeń pro futuro w żadnym razie nie może sprowadzać się jedynie do sprzeciwu wyrażonego przez pacjenta, powinna również zawierać preferencje jednostki. Pacjent za pomocą oświadczeń woli pro futuro może nie tylko wskazać, na jakie świadczenia nie wyraża zgody, ale może także wyrazić stosowne życzenia co do dalszego leczenia, tak więc prawidłowo sporządzony testament życia powinien zawierać katalog czynności, których w stosunku do pacjenta nie będzie można wykonać.

Należałoby więc zastosować takie rozwiązanie, które pozwoli na złożenie oświadczenia woli bez późniejszego niebezpieczeństwa pomyłek lub nadużyć. Gdyby rodzimy ustawodawca przyjął wymóg formułowania oświadczeń $\mathrm{w}$ jednej z form szczególnych, wówczas zwalniałoby to pracownika służby zdrowia $\mathrm{z}$ analizy merytorycznej takiego oświadczenia. Ciężar związany z badaniem oświadczenia $\mathrm{w}$ zakresie jego wiarygodności i zgodności z rzeczywistą wolą pacjenta nie powinien być przerzucany na osoby wykonujące zawody medyczne. Rozważając przykład przerwania leczenia w fazie terminalnej, należy wskazać, że decyzja o tym nie jest wyłącznie kwestią czysto medyczną, ale stanowi także wybór etyczny. Przejrzysta regulacja określająca zasady wyrażania i poszanowania uprzedniej woli pacjenta pozwoliłaby na zwolnienie lekarzy z obowiązku rozważania tych przenikających się i z tego powodu skomplikowanych kwestii.

\footnotetext{
13 B. Janiszewska, Dobro pacjenta czy wola pacjenta - dylemat prawa i medycyny (uwagi o odmowie zgody na leczenie oraz o dopuszczalności oświadczeń pro futuro), „Prawo i Medycyna” 2007, nr 2, s. 46.

14 M. Boratyńska, Niektóre aspekty świadomej zgody pacjenta na leczenie na tle orzecznictwa Sądu Najwyższego. Część 1. Sprzeciw pro futuro, „Prawo i Medycyna” 2007, nr 2, s. 25.
} 
Wybrane problemy związane z wprowadzeniem do ustawodawstwa polskiego...

Warto też poruszyć sprawę stosunku zależności działań lekarzy od stanowiska rodziny niekompetentnego pacjenta. Znaczenie dla lekarzy ma fakt, czy rodzinie faktycznie zależy na dobru chorego, czy członkowie rodziny są zgodni w swojej opinii, a opinia ta jest racjonalna. Wypracowanie modus vivendi z rodziną pacjenta nie należy do łatwych zadań, bowiem może rodzić ryzyko scedowania zbyt dużej odpowiedzialności za decyzje medyczne na najbliższych. Jednocześnie ważne jest także zachowanie stosownego respektu do wątpliwości członków rodziny pacjenta ${ }^{15}$.

W prawie polskim nie istnieją regulacje wskazujące na konieczność respektowania uprzednich oświadczeń woli, jednak Sąd Najwyższy postanowieniem z dnia 27 października 2005 r. stwierdził, że: „oświadczenie pacjenta wyrażone na wypadek utraty przytomności, określające wolę dotyczącą postępowania lekarza [...] w sytuacjach leczniczych, które mogą zaistnieć w przyszłości, jest dla lekarza - jeżeli zostało złożone w sposób wyraźny, jednoznaczny i nie budzi wątpliwości - wiążące"16. W dalszej części tego postanowienia sąd zaznaczył, że „zasada poszanowania autonomii pacjenta nakazuje respektowanie jego woli, niezależnie od motywów (konfesyjnych, ideologicznych, zdrowotnych itp.), toteż należy przyjąć, że brak zgody pacjenta na określony zabieg (rodzaj zabiegów) jest dla lekarza wiążący i znosi odpowiedzialność karną lub cywilną, natomiast w wypadku wykonania zabiegu delegalizuje go". Dlatego pomimo braku odpowiednich regulacji testament życia w naszym kraju zgodnie ze stanowiskiem judykatury - jest dopuszczalny.

\section{Wątpliwości dotyczące kwestii aktualności testamentu życia}

W tym miejscu chciałybyśmy przejść do trudnej kwestii aktualności testamentu życia wobec znalezienia się pacjenta w rzeczywistej sytuacji leczniczej. Przeciwnicy testamentów życia podnoszą, że człowiek w sytuacji zagrożenia życia zachowuje się inaczej niż w stanie pełnego zdrowia, a co za tym idzie, wola człowieka może w obliczu choroby ulec zmianie. Osoba zdrowa inaczej ocenia wartość i jakość życia. Sporządzając testament życia, jednostka może nie życzyć sobie dalszej egzystencji, znajdując się w krytycznym stanie zdrowia, szczególnie będąc zupełnie zależną od innych i wymagającą całodobowej opieki.

Jak słusznie zauważa M. Machinek, zarówno doświadczenie, jak i badania udowadniają, że ludzie zdrowi w swoich testamentach życia znacznie częściej odrzucają pewne interwencje lekarskie, niż ci, którzy formułują takie oświadczania ze świadomością niepomyślnej diagnozy ${ }^{17}$.

\footnotetext{
15 J. Hartman, Bioetyka dla lekarzy, Warszawa 2012, s. 111.

16 Postanowienie SN z dnia 27 października 2005 r., III CK 155/05, OSNC 2006, nr 7-8, poz. 137.

17 M. Machinek, Etyczna problematyka testamentu życia i innych oświadczeń pro futuro. Głos w dyskusji. Debata wokół testamentu życia 23.11-30.11.2009, www.ptb.org.pl/pdf/machinek_testament, (data dostępu: 15.07.2016 r.).
} 
Jako przykład podaje się historię znanego niemieckiego profesora Waltera Jensa - zwolennika eutanazji, który zdecydowanie opowiadał się za możliwością rezygnacji z jakichkolwiek działań podtrzymujących życie. Gdy zachorował przestał rozpoznawać bliskich i wymagał pełnej opieki. Znamiennym jest, że wśród nielicznych słów, jakie kierował do najbliższych, najczęściej mówił: „proszę mnie nie zabijać”. Sytuacja ta pokazuje, że pacjent może zmienić zdanie. Czy w ten sposób wyartykułowana wola zmieniła wcześniejsze oświadczenie woli, które przecież złożył, kiedy był w pełni świadomy i korzystający ze swej autonomii ${ }^{18}$ ? Tu pojawia się pytanie, który testament życia należy respektować?

Naszym zdaniem, jeśli pojawiają się wątpliwości co do wcześniej wyrażonej woli pacjenta, a są nimi niewątpliwie późniejsze słowa wypowiadane przez chorego, lekarze powinni powstrzymać się z realizacją wcześniejszego oświadczenia. Intuicja moralna przemawia przeciwko bezwzględnemu respektowaniu woli pacjenta wyrażonej przez niego $\mathrm{w}$ warunkach autonomicznego samostanowienia, jeśli później zmienił swoją wolę. Jak uważa T. Dukiet-Nagórska „skoro nie ma wątpliwości co do tego, że pacjent ma prawo w sposób świadomy odmówić poddania się działaniu lekarskiemu, to - tak długo, jak długo nie ma podstaw dla podważenia autentyczności jego oświadczenia, jak też wątpliwości co do tego, czy pacjent nie zmienił stanowiska, należy jego wolę respektować" ${ }^{\prime 1}$. Według J. Hartmana, jeśli lekarz nie może zakładać, że wola pacjenta wyrażona zanim znalazł się w dramatycznej sytuacji, jest tym samym, co jego aktualna wola, ma także podstawę do tego, aby wątpić w wartość testamentu życia tym bardziej, im więcej jest w nim zastrzeżeń przeciwko interwencjom lekarskim ${ }^{20}$.

Wobec powyższych rozważań, należy wziąć pod uwagę, że człowiek może zmienić swoje zdanie, nawet jeśli nie znajduje się w obliczu śmierci, dlatego też polski ustawodawca, chcąc uregulować problematykę testamentów życia, powinien wprowadzić czasowość obowiązywania takich oświadczeń. Można postulować, aby każda osoba, która złoży oświadczenie pro futuro, po upływie kilku lub kilkunastu lat je zaktualizowała.

\section{Wybrane regulacje prawne innych państw}

Rozważając problem testamentów życia, warto zwrócić uwagę na to, jak kwestie te zostały uregulowane $\mathrm{w}$ innych krajach, ale przedstawimy jedynie wybrane rozwiązania, które naszym zdaniem warto byłoby wziąć pod uwagę przy regulacji problematyki testamentu życia w Polsce, zwracając zwłaszcza uwagę na instytucje szczególnego rodzaju pełnomocników.

J. Haberko, Realizacja standardów bioetycznych..., op. cit., s. 144.

T. Dukiet-Nagórska, Autonomia pacjenta a polskie prawo karne, Warszawa 2008, s. 63.

J. Hartman, Bioetyka dla lekarzy, op. cit., s. 110. 
Wybrane problemy związane z wprowadzeniem do ustawodawstwa polskiego...

Mimo że w Belgii eutanazja jest dopuszczalna, to istnieje wyraźne rozróżnienie tej problematyki od oświadczeń pro futuro. Kwestie te zostały uregulowane w oddzielnych aktach normatywnych, co zapobiega pomieszaniu obu instytucji. W Belgii na aprobatę zasługują zasady takie jak: wiążący charakter oświadczeń pro futuro, kompleksowość regulacji oraz odniesienie się do różnych postaci tych oświadczeń. Jeśli chodzi o kompleksowość regulacji, to wyraża się ona między innymi w Ustawie o prawach pacjenta z dnia 22 sierpnia 2002 r., która miała na celu usystematyzowanie praw pacjenta i zwiększenie ich ochrony ${ }^{21}$. Wspomniana ustawa wprowadza instytucje takie, jak: deklaracje antycypowane, czyli oparte na dokładnym poinformowaniu pacjenta, osoby zaufania i pełnomocnik do spraw zdrowotnych. Osoba zaufania działa tylko i wyłącznie, jeśli pacjent pozostaje przytomny, natomiast w wypadku utraty przez niego świadomości prawo belgijskie przewiduje pełnomocnika do spraw zdrowotnych, z czego wynika, że wyznaczenia personne de confiance nie zaliczamy do problematyki oświadczeń pro futuro. Rola tej osoby polega na wsparciu pacjenta w procesie informacyjnym. Lekarz przekazuje informacje zarówno pacjentowi, jak też osobie zaufania, dlatego ustanawia się go, kiedy pacjent ma problemy w zrozumieniu informacji z powodu stanu, w jakim się znajduje. Zadanie pełnomocnika do spraw zdrowotnych rozpoczyna się w przypadku utraty przytomności przez pacjenta i trwa aż do odzyskania możliwości podejmowania świadomych, samodzielnych decyzji. Pełnomocnik do spraw zdrowotnych jest jakby zastępcą pacjenta, ponieważ posiada pełen zakres praw przyznanych pacjentowi. Rozwiązania belgijskie bazują na poszanowaniu prawa człowieka do samostanowienia, odwołując się do ochrony godności człowieka. Relacje między pacjentem a lekarzem są ułożone na zasadzie partnerstwa, wzajemnego szacunku oraz dialogu ${ }^{22}$.

Ustawodawca szwajcarski również wprowadził instytucję specjalnego pełnomocnika. Pełnomocnictwo to jest szczególnym rodzajem pełnomocnictwa cywilnego, zawiera kompleksowe uprawnienia - oprócz decydowania w sprawach medycznych, pełnomocnik może także zarządzać majątkiem mocodawcy i reprezentować go w stosunkach prawnych $\mathrm{z}$ osobami trzecimi. Uprawnienia pełnomocnika powinny zostać określone $\mathrm{w}$ treści pełnomocnictwa, przy czym pełnomocnikiem może być osoba fizyczna lub prawna, a dokument może być sporządzony w formie holograficznej lub notarialnej. Ustawodawca przewidział sposób przechowywania pełnomocnictwa oraz możliwość jego zarejestrowania w specjalnej bazie danych. Należy pamiętać o tym, że pełnomocnictwo jest skuteczne jedynie wówczas, gdy mocodawca nie ma zdolności do samodzielnego prowadzenia swoich spraw.

W Szwajcarii przyjęto ciekawe rozwiązanie zakładające, że pacjentowi powinien towarzyszyć ktoś, kto będzie dla lekarza zarówno partnerem, jak i przeciwwagą. Jest

\footnotetext{
21 Ustawa z dnia 22 sierpnia 2008 r. o prawach pacjenta (Moniteur Belge, MB z dnia 26 września 2002 r., nr 2002022737, s. 43719).

22 M. Syska, Medyczne..., op. cit., s. 151-153.
} 
to specyficzny system przedstawicielstwa ustawowego na wypadek utraty przytomności, w przypadku gdy pacjent nie sporządził oświadczenia pro futuro, ani nie ustanowił pełnomocnika do spraw zdrowotnych. Osobą, która może pełnić taką rolę, jest małżonek lub zarejestrowany partner, pod warunkiem, że prowadzili wspólnie gospodarstwo domowe lub partner stale opiekował się pacjentem. W takim wypadku lekarz obowiązany jest włączyć osobę bliską do procesu decyzyjnego, w szczególności udzielać jej wszelkich, niezbędnych informacji o stanie zdrowia chorego. Wszystkie rodzaje oświadczeń pro futuro, a także decyzje przedstawicieli ustawowych mają charakter wiążący dla lekarzy. Ustawodawca szwajcarski słusznie uznał, że jeśli nieprzytomny czy niekompetentny pacjent nie ma już wpływu na swoje leczenie, to lepiej będzie, jeśli decyzje będą podejmowały osoby zaufane dla pacjenta, niż miałby o tym decydować sąd. Zostały również sformułowane kryteria, jakimi mają kierować się przedstawiciele. Rekonstruują oni wolę pacjenta na podstawie ogólnej wiedzy o nim. Decyzja taka powinna być nie tylko zgodna z wolą pacjenta, ale również chronić jego interes.

Prawo angielskie nie posługuje się instytucją osoby zaufania, można natomiast upoważnić określoną osobę do dostępu do dokumentacji medycznej, jednak bez możliwości decydowania przez upoważnionego o leczeniu chorego. W zakresie kompetencji takiej osoby pozostaje więc jedynie prawo do zapoznania się z informacjami o stanie zdrowia oraz udzielanymi świadczeniami zdrowotnymi ${ }^{23}$. W Anglii autonomia pacjenta jest chroniona także poprzez instytucje wiążących dyrektyw antycypowanych oraz możliwość ustanowienia pełnomocnika do spraw zdrowotnych. Mocodawca może upoważnić swojego pełnomocnika do decydowania o jego sprawach osobistych i majątkowych, może również ograniczyć jego uprawnienia do działania w ściśle określonych sytuacjach faktycznych lub ograniczyć jego kompetencje tylko do określonych czynności. Dyrektywa antycypowana jest nieważna, jeśli składający skutecznie ją cofnął lub ustanowił pełnomocnika do spraw zdrowotnych i to mu powierzył prawo do decydowania o leczeniu, którego zakres był wskazany w dyrektywie. Decyzja co do sporządzenia takiej antycypowanej dyrektywy musi być przemyślana, gdyż zmusza składającego do precyzyjnego określenia sytuacji leczniczych. W odniesieniu do formy, brak jest szczególnych wymagań, co za tym idzie dyrektywy mogą być składane w dowolnej formie, nie tylko pisemnej. Pełnomocnictwo do spraw zdrowotnych stosuje się w momencie, gdy mocodawca nie jest zdolny do samodzielnego wyrażenia lub odmowy zgody. Jeśli po ustanowieniu pełnomocnika mocodawca sporządzi dyrektywę antycypowaną, wówczas ma ona pierwszeństwo i wyłącza kompetencje pełnomocnika do podejmowania decyzji dotyczących leczenia określonego w dyrektywie ${ }^{24}$.

A. Sporczyk, Oświadczenia woli pro futuro w prawie francuskim i anglosaskim, „Prawo i Medycyna” 2015, nr 1 (58, vol. 17), s. 63 i nast. 
Wybrane problemy związane z wprowadzeniem do ustawodawstwa polskiego...

Ciekawe jest to, że sąd opiekuńczy, który ma podjąć decyzję, w szczególnych sytuacjach może wyznaczyć przedstawiciela osoby niezdolnej. W ustawodawstwie angielskim w przypadku podejmowania decyzji dotyczącej osoby niezdolnej do samostanowienia istnieje obowiązek działania w interesie pacjenta. Obowiązek ten ma charakter obiektywny, jak i subiektywny, oznacza to, że podejmowane są próby włączenia pacjenta w proces decyzyjny. Bardzo wyraźny jest nakaz rekonstruowania woli osoby niezdolnej w oparciu o jej wcześniejsze życzenia i wyrażane poglądy. W przypadku gdy zawiodą wszelkie sposoby poznania życzeń pacjenta, korzysta się z instytucji kuratora lub doradcy wyznaczonego dla osoby niezdolnej do samostanowienia, u którego należy zasięgnąć opinii.

\section{Wnioski i postulaty de lege ferenda}

W Polsce wciąż trwa ożywiona dyskusja na temat testamentu życia ${ }^{25}$. Argumenty zwolenników i przeciwników testamentów życia zależą głównie od ich subiektywnych przekonań i światopoglądu. Formułując swoje wypowiedzi, kierują się przede wszystkim przyjmowanymi przez siebie wartościami moralnymi oraz wiarą. To pokazuje, że dyskurs ten nie może skończyć się konsensusem. Niezwykle trudno będzie znaleźć uniwersalny model testamentu życia, który byłby do przyjęcia przez obie strony tego sporu.

Zwolennicy testamentów uważają, że jest to wyraz poszanowania wolnej woli człowieka i przyznania mu prawa do wyboru czasu i okoliczności odejścia z doczesnego świata. Przeciwnicy natomiast stanowczo podkreślają, że te oświadczenia są próbą wprowadzenia prawnej zgody na ukrytą eutanazję. Ludzie, którzy opowiadają się za przyjęciem testamentów życia, uważają, że dzięki nim nie muszą obarczać bliskich osób opieką nad sobą w czasie nieuleczalnej choroby. Uważają także, że testamenty nie dopuszczają do trwania przez człowieka w sytuacji dla niego niegodnej. Z drugiej strony inni twierdzą, że niesie to ryzyko żonglowania ludzkim życiem.

Uważamy, że testamenty życia są wyrazem poglądów ludzi żyjących we współczesnych czasach. Chcemy kontrolować wszystkie sfery swego życia, nawet te ostateczne, nie godząc się z tym, co przynosi nam los. Należy pamiętać, że nie można odebrać prawa do decydowania osobom, które kategorycznie odmawiają utrzymywania ich przy życiu w określonym stanie. Argumenty obu stron równoważą się w dyskusji, z tego powodu przy regulowaniu zagadnienia testamentu życia, tak ważne jest branie pod uwagę obu stanowisk. Jest to prawdziwe wyzwanie dla ustawodawcy, gdyż instytucje dotykające subiektywnych odczuć każdego człowieka zawsze są niezwykle trudne do ujęcia w ramy przepisów prawa. 
Życie przyjmowane jest za wartość dla prawa najważniejszą, dlatego żaden system prawny nie powinien unikać zajęcia stanowiska wobec rodzącej się potrzeby uregulowania kluczowych kwestii. Procedura ustawodawcza odnosząca się do analizowanej problematyki nie jest sprawą wyłącznie pomiędzy ustawodawcą a gronem ekspertów, a skoro dotyczy wrażliwych sfer dotyczących całego społeczeństwa, to społeczeństwo powinno mieć silny głos w tej dyskusji.

$\mathrm{W}$ tym miejscu chcemy uwypuklić nasze spostrzeżenia i rozwiązania z państw obcych, które należałoby wziąć pod uwagę regulując testamenty życia:

- oświadczenia pro futuro w formie pozytywnej i negatywnej, czyli dopuszczenie nie tylko formy sprzeciwu ale także zgody określającej preferencje jednostki;

- wymóg sporządzania testamentów życia w formie szczególnej, np. forma pisemna pod rygorem nieważności, rodzaj testamentu holograficznego lub notarialnego;

- respektowanie zmian wcześniejszego testamentu życia, nawet jeśli zmiana była dokonana w warunkach innej kondycji psychofizycznej;

- konieczność wprowadzenia czasowości i obowiązku aktualizacji testamentu życia;

- wprowadzenie przejrzystości pojęciowej, co pozwoli uniknąć pomylenia różniących się instytucji;

- wprowadzenie instytucji przedstawiciela ustawowego dla pacjentów, którzy nie sporządzili oświadczeń pro futuro.

\section{BIBLIOGRFIA}

Boratyńska M., Niektóre aspekty świadomej zgody pacjenta na leczenie na tle orzecznictwa Sądu Najwyższego. Część 1. Sprzeciw pro futuro, „Prawo i Medycyna” 2007, nr 2.

Chańska W., Ewolucja dyrektyw na przyszłość w amerykańskiej praktyce medycznej, „Prawo i Medycyna" 2015, nr 1.

Dukiet-Nagórska T., Autonomia pacjenta a polskie prawo karne, Warszawa 2008.

Górski A. (red.), Leksykon pojęć prawa medycznego, Warszawa 2012.

Haberko J., Realizacja standardów bioetycznych w prawie polskim w zakresie oświadczeń pro futuro, (w:) L. Kondratiewa-Bryzik, K. Sękowska-Kozłowska (red.), Prawa człowieka wobec rozwoju biotechnologii, Warszawa 2013.

Hartman J., Bioetyka dla lekarzy, Warszawa 2012.

Jachnik E., Testament życia w świetle Europejskiej Konwencji Bioetycznej, a możliwość składania oświadczeń pro futuro w prawie polskim, „Zeszyt studencki Kół Naukowych Wydziału Prawa i Administracji UAM" 2014, nr 4.

Janiszewska B., Dobro pacjenta czy wola pacjenta - dylemat prawa i medycyny (uwagi o odmowie zgody na leczenie oraz o dopuszczalności oświadczeń pro futuro), „Prawo i Medycyna” 2007, nr 2. 
Janiszewska B., Odmowa zgody na udzielenie świadczenia zdrowotnego w orzecznictwie Sądu Najwyższego, (w:) L. Bosek, M. Królikowski, Współczesne wyzwania bioetyczne, Warszawa 2010.

Łabowicz B., Testament życia, (w:) W cieniu czepka, „Biuletyn informacyjny dolnośląskiej okręgowej izby pielęgniarek i położnych” 2014, nr 2/268/luty.

Machinek M., Konflikty etyczne u kresu życia w relacji lekarz-pacjent: refleksja w kontekście projektu powołania szpitalnych komisji etycznych, „Diametros” nr 22, 64-75, 2009.

Machinek M., Etyczna problematyka testamentu życia i innych oświadczeń pro futuro. Głos w dyskusji. Debata wokół testamentu życia 23.11-30.11.2009. www.ptb.org.pl/pdf/machinek_testament, (data dostępu: 15.07.2016 r.).

Safjan M., Prawo i medycyna, ochrona praw jednostki a dylematy współczesnej medycyny, Warszawa 1998.

Sporczyk A., Oświadczenia woli pro futuro w prawie francuskim i anglosaskim, „Prawo i Medycyna” 2015, nr 1.

Syska M., Medyczne oświadczenia pro futuro, Warszawa 2013.

Szeroczyńska M., Dopuszczalność uprzednich oświadczeń pacjenta i pełnomocnictwa medycznego de lege lata i de lege ferenda, www.hospicjum.waw.pl

Śliwka M., Testament życia i inne oświadczenia pro futuro - przyczynek do dyskusji, www.ptb.org.pl/ pdf/sliwka_testament_1.pdf, (data dostępu: 30.03.2016 r.).

Śliwka M., Testament życia oraz inne oświadczenia pro futuro - wyzwanie dla ustawodawcy polskiego, (w:) Temida w dobie rewolucji biotechnologicznej, Gdańsk 2015.

http://www.miesiecznik.znak.com.pl/6672010andrzej-zollprawo-wobec-narodzin-zycia-i-smierci/, (data dostępu: 04.07.2016 r.).

http://www.polityka.pl/tygodnikpolityka/kraj/276734,1,etyka-w-zarodku.read, (data dostępu: 30.06.2016 r.). 